Global Conferences Series:

Sciences and Technology (GCSST), Volume 3, 2020

The $1^{\text {st }}$ International Conference on Education, Sciences and Technology

DOI: https://doi.org/10.32698/tech3245

\title{
How to Manage Dynamic Archive Record Based On E- Agenda at School?
}

\author{
Nina Oktarina*, Joko Widodo, Kardoyo \\ Universitas Negeri Semarang, Indonesia 50229 \\ ninaoktarina@mail.unnes.ac.id
}

\begin{abstract}
The aim of this research was to develop dynamic archive record at school based on E-Agenda. The use of manual recording systems at school is not effective because the archive search cannot be done quickly and accurately. The dynamic archive record was developed based on Ms. Access program. It was a Research and Development (R\&D) study. The data were collected by interview, observation, questionnaire, and documentation. The data were analysed quantitatively; it was t-test on the paired data to test the difference of the actual and the new model. It was also analysed qualitatively through the data triangulation. The results showed that e-agenda system can support better archive management. The archive search can be done quickly and accurately Therefore; it is suggested for school management to implement eagenda system, because e-agenda does not require expensive fees to design it and easy to implement.
\end{abstract}

Keywords: E-Agenda, Dynamic Archive, Management, Archive record

\section{INTRODUCTION}

Industrial Revolution 4.0 as a development of modern civilization, its impact on various aspects of life, the penetration of technology that is all disruptive, makes change faster as a consequence of the phenomenon of the Internet of Things (IoT), big data, automation, robotics, cloud computing, artificial intelligiance. One of the effects of the fourth industrial revolution is the automation and reduced number of human labor in production. As in the management of dynamic records in schools it must be changed from manual management to automation.

Archive management is one of the most important administrative functions in school organization. It is impossible to plan and administer any formal organization effectively in which archives are not properly kept or mismanaged. To successfully achieve effective school archive must be safely kept and properly managed. School archive can therefore be defined as information keeping documents on school administration [1]. They are at times referred to as the encyclopaedia of school activities. Most of them are kept because education law of the country requires that they must be kept. School archives are also kept because of the useful information they provide about the students, teachers, the school and the educational system in general.

Archive management is the systematic control of an organizations vital documents and records. According [2], archive management at school is the administrative responsibility of both principals

Copyright (C) 2019, the Authors. Published by Redwhite Press.

Page | 121

This is an open access article under the CC BY-NC license

(http://creativecommons.org/licenses/by-nc/4.0). 
and teachers to embrace ideal administrative practices that ensures effective and efficient school archive keeping in school system.

Management archive constitutes the arteries that supply life-sustaining blood to the system and subsystems of organizations and institutions [3]. It will definitely be an impossible task to plan and administer any known organization in which archives are not kept, or are carelessly or fraudulently kept. The education system as a social organization has numerous sub-systems or levels that are managed to ensure some coherence and continuity. To successfully achieve this, records must be stored in such a way that they are accessible and safe guarded against environmental damage. The school must be very careful in keeping the archives, checking and crosschecking every item of information going out under their signatures.

Archive management ensures information can be accessed easily, can be destroyed routinely when no longer needed, and enables schools not only to function on a day to day basis, but also to fulfil its legal and financial requirements. [4] defines archive management as "the field of management responsible for the efficient and systematic control of the creation, receipt, maintenance, use and disposition of archive, including the processes for capturing and maintaining evidence of information about business activities and transaction in the form or records or archive".

Archive management is all encompassing, since it stipulates how archives should be managed even before it is created to the point of disposition or retention in the archives. Therefore, archive management can be one of the most important functions for many other reasons. Archives are the lifeblood of any institution. As very important function for school archive is also strategically important that archivists believe in the archive management has impact on administrative education [5]. It is impossible to plan and administer any formal organization effectively in which archives are not properly kept or mismanaged.

To successfully achieve effective school archive must be safely kept and properly well managed in order to ensure they are protected both administrative purposes and to serve as evidence of the institution's work. The scarce resources in schools may be wasted if their utilization and underutilization is not properly recorded [6]. School archive can therefore be defined as information keeping documents on school administration. They are at times referred to as the encyclopaedia of school activities. Most of them are kept because education law of the country requires that they must be kept. School archives are also kept because of the useful information they provide about the students, teachers, the school and the educational system in general.

Similar with[7] stated that school archives are seen as the collection of information on school personal (students, teacher and non-teacher), facilities, funds and school activities which are preserved for future use or reference purposes. According to[8], school archives are official documents, books and files containing essential and crucial information of actions and events which are kept and preserved in the school office for utilization and retrieval as needed.

There is a need to keep archive of all school activities as part of effective school administration. The management of archive is a vital responsibility of the school administrator because of the indispensable role of archives and information in the day-to-day activities of the school system. School managers rely on the short and long-term data captured in records to make effective decisions about immediate issues and more comprehensive school policies .

asserts that without records there can be no accountability. [9] stated that the effective of archive management at institution provide information required for the proper functioning of organizations, including schools. The net effect of poor management of archive at institution is a decrease in efficiency of institution and an inflation of its operating costs [10]. Archive management is the systematic control of an organizations vital documents and records. In essence, sound archive management is the foundation any higher educational institution needs to provide services, to fulfil its obligation of accountability towards immediate community, students and staff and to protect their rights[11]). No institution can survive without keeping archives of its activities and also no office could operate successfully if it had to rely on memory alone to keep track of every transaction [12].

Archive management at school is the administrative responsibility of both principals and teachers to embrace ideal administrative practices that ensures effective and efficient school archive keeping in 
school system. Management archive constitutes the arteries that supply life-sustaining blood to the system and sub-systems of organizations and institutions. It will definitely be an impossible task to plan and administer any known organization in which archives are not kept, or are carelessly or fraudulently kept.

The education system as a social organization has numerous sub-systems or levels that are managed to ensure some coherence and continuity. To successfully achieve this, records must be stored in such a way that they are accessible and safe guarded against environmental damage. The school must be very careful in keeping the archives, checking and crosschecking every item of information going out under their signatures.

In the Ghanian Educational System, it is mandatory by law that all educational institution keeps certain archive. The management of archive at school is often organized around a life cycle that all archive should follow i.e. creation, storage, retrieval (for use as needed), retention and disposition which includes protecting all vital documents (records/archives).

Based on the results of observation about archives management at high school in Semarang city, their archival recording system is still using the manual agenda book. The facts in the field indicate the recording archives with manual systems were not effective. Problem that often occurs was difficult to know quickly about the number of archives received daily, weekly, monthly, and annually. It also takes a long time when will identify the information content of the incoming or outgoing archives. The problems faced by the administration was the large number of letters were made and accepted by the administration of school that makes data retrieval becomes inefficient. This is because the archiving process is still using the manual system in which every incoming and outgoing mail are recorded in the books and not computerized. In essence, every school in Indonesia was using manual book agenda to record their letter. Manual agenda book is a book that used to record the incoming and outgoing mail within one year. In addition, in line with the results research of [13] stated that the archives management at the high schools in Semarang city were still using manual system so it was ineffective. While the existence of the archive to support the school accountability is very important.

Based on the results of research [14] about the development of school accountability model based on archives, it was known that the majority of high schools in Semarang city still use manual system for management of archive, beside those only four schools have used computerized system. The details are as follows.

Table 1

Archive System at School

\begin{tabular}{|c|c|c|c|}
\hline No & Accreditation & $\begin{array}{c}\text { Number } \\
\text { of } \\
\text { Schools }\end{array}$ & Information \\
\hline \multirow[t]{2}{*}{1} & A & 53 & $\begin{array}{l}\text { Four schools were } \\
\text { using the } \\
\text { computerized } \\
\text { system, } 49 \text { schools } \\
\text { were }\end{array}$ \\
\hline & & & $\begin{array}{l}\text { still using manual } \\
\text { system }\end{array}$ \\
\hline 2 & B & 25 & $\begin{array}{l}25 \text { schools were } \\
\text { using manual system }\end{array}$ \\
\hline 3 & $\mathrm{C}$ & 16 & $\begin{array}{l}16 \text { schools were } \\
\text { using manual system }\end{array}$ \\
\hline 4 & New School & 2 & $\begin{array}{l}\text { Two schools were } \\
\text { using manual system }\end{array}$ \\
\hline \multicolumn{2}{|r|}{ Total } & 96 & \\
\hline
\end{tabular}


Recording of archive with manual systems are ineffective in school resulted in the archive management at the school was not optimal. Therefore, the efforts to overcome the ineffectiveness of archives recording at school are by designing and developing E-Agenda system. E-agenda system that will be developed based on Ms Access program.

\section{RESEARCH METHODOLOGY}

This study was designed with a research and development approach which based on the principles and steps of [15], by simplifying the steps into four stages: (1) stage of preliminary study, (2) stage of development model, (3) stage of validation and limited testing to find a final hypothetical models, and (4) the stage of determination model which is finding the final and dissemination model. The stage of preliminary study was carried out in SMA 12 Semarang, SMA Al Uswah, and SMA Widya Wiyata. The three schools have represented the school that has accreditation of A, B, and C.

The stage of design development of the E-agenda System to support the archive management at school with experts through FGD and consultation/discussion. The stage of validation and the limited tests will be performed on the object of research and validation internally with colleagues and experts. The fourth stage is the external validation with implementation models to find the final model and dissemination.

\section{Data Sources, Data Types and Data Collection Techniques}

The data source is distinguished into two, namely human and non-human. Human data sources have function as subjects or key informants. While non-human data sources come from the documents of organization and related agencies. Determination of informants as a data source was using purposive sampling techniques or by certain considerations that is knowing and involved in the management of archives at the school. These data sources include the principal, vice principal, teachers, administration officer at the school. Sources and data collection techniques and also research subjects can be seen in table 4 below.

Table 2

Sources and Data Collection Techniques

\begin{tabular}{|l|l|l|}
\hline $\begin{array}{c}\text { The Purpose of } \\
\text { Research }\end{array}$ & $\begin{array}{c}\text { Data Sources } \\
\text { (People) }\end{array}$ & $\begin{array}{c}\text { Data } \\
\text { Collection } \\
\text { Techniques }\end{array}$ \\
\hline $\begin{array}{l}\text { 1. Known the } \\
\text { implementatio } \\
\text { n of the } \\
\text { registration } \\
\text { archives and } \\
\text { constraints so } \\
\text { far. }\end{array}$ & $\begin{array}{l}\text { Principal, Vice } \\
\text { Peachers, } \\
\text { Administration } \\
\text { Officer, Expert }\end{array}$ & $\begin{array}{l}\text { Interview, } \\
\text { observation, } \\
\text { and } \\
\text { denified }\end{array}$ \\
$\begin{array}{l}\text { components } \\
\text { related to the } \\
\text { archive } \\
\text { management } \\
\text { at school. }\end{array}$ & \\
3. Arranged the \\
design of E- \\
Agenda \\
System to
\end{tabular}




\begin{tabular}{|c|c|c|}
\hline $\begin{array}{l}\text { The Purpose of } \\
\text { Research }\end{array}$ & $\begin{array}{c}\text { Data Sources } \\
\text { (People) }\end{array}$ & $\begin{array}{c}\text { Data } \\
\text { Collection } \\
\text { Techniques }\end{array}$ \\
\hline $\begin{array}{l}\text { support the } \\
\text { archives } \\
\text { management } \\
\text { at school }\end{array}$ & & \\
\hline $\begin{array}{l}\text { The } \\
\text { effectiveness of } \\
\text { E-Agenda } \\
\text { System Model } \\
\text { to support the } \\
\text { archive } \\
\text { management at } \\
\text { school }\end{array}$ & $\begin{array}{l}\text { Principal, } \\
\text { Academician, } \\
\text { Vice Principal, } \\
\text { Teachers, } \\
\text { Administration } \\
\text { Officer, Expert }\end{array}$ & $\begin{array}{l}\text { Questionnaire } \\
\text { with question } \\
\text { form, then it } \\
\text { will be } \\
\text { analysed by T- } \\
\text { Test }\end{array}$ \\
\hline
\end{tabular}

The data analysis process begins by reviewing all available data from various sources, namely from interviews, observation, documents, photographs, images and so on [16]. In this study uses data analysis during field, namely when the data collection in the field is ongoing, according to [17] through the activity data i.e. reduction data, display data, and conclusion drawing/verification. As for the test of the effectiveness of the model using T-Test. This study uses principles and the steps of Borg and Gall, but could not be applied in full because of the limitations of the researcher, then the steps are simplified into four stages: (1) stage of preliminary study i.e. drawing up the design of conceptual model based on theory and field studies; (2) stage of model development by drawing up the design of the model; (3) stage of internal validation through the FGD with colleagues and experts as well as a limited trial; (4) stage of expanded trial and dissemination of final model that recommended.

\section{RESEARCH FINDING AND DISCUSSION}

Good archive management has an important role in an organization. The school as an organization that provides educational services in each activity could not be detached from the archive. Ineffective management of archives will interfere the running of school activities. The position of the archives at the school is supporting documents in the giving of information and reports related to the performance of the school. Therefore, the effective of archive management will support the achievement of the school accountability. But the facts in the field indicate that the archive management at school has not been effective.

Management of archive includes planning, controlling, directing, organizing, training, developing, and other managerial activities that aimed at the activities of the creation, maintenance, use and depreciation of archives. These activities are intended to achieve a good documentation and in accordance with policies and transactions (events, incident, and activities) are real, and operation management organization that is effective and efficient.

Management of archives that are organized by the school still use manual systems. The use of a manual system is causing problems in the finding of archive and searching the source archive. One of the stages in the management of archives is recording an archive. Now, the archive recording system conducted by school is using the agenda book. This system is not effective because it is not able to know the existing archive volume quickly. In addition, the information about the origin of archives cannot be known quickly. Beside that recording archive has not classification for certain parts. This problem can be overcome by developing an archival recording system-based technology. 
The system developed is E-Agenda system based on Ms Access program. Ms Access program that had more utilized for inventory logistics, but this study will be developing for E-Agenda system in recording the archive at school. This system is simple and easy to be applied. E- Agenda system designed by dividing into four menus, namely curriculum, facilities, students, and public relations. The details of the menu as in Figure 1.

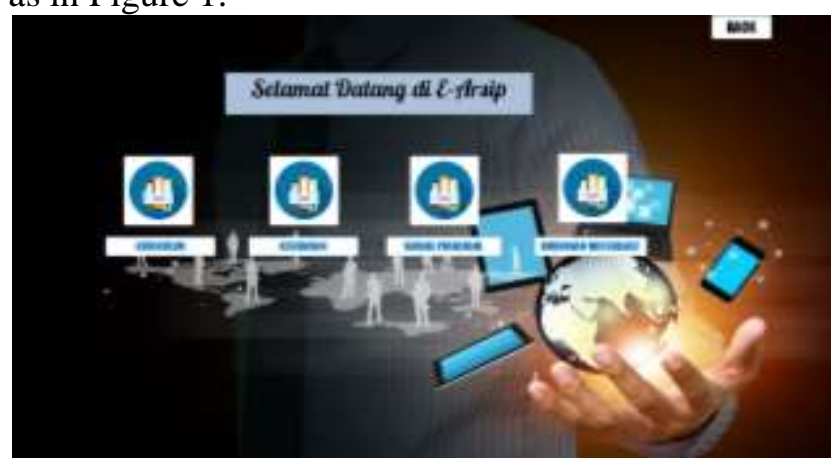

Figure 1 First Menu of E-Agenda

The steps for using E-Agenda System application begins by double click icon on menu of Ms Access, then login to E-Agenda System. How to login to the application of E-agenda School system can use the username and password, we can use username: NINA and password: OKTARINA.

On the display of homage menu, there are four types of menu E-Agenda for school archives include (1) Menu of curriculum archive, (2) Menu of Student Archive, (3) Menu of Facilities and Infrastructure Archive, and (4) Menu of Public Relation Archive. Each menu has the functions and benefits of appropriate field.

In the menu of curriculum archive, there is only one menu about all kinds of document relating to the areas of the curriculum. The next menu in E-agenda system is student affairs archive. After that menu is about menu of facilities/infrastructure archive.

The last menu in the application of E-Agenda System for school archive is menu of public relations. In this menu, there are three submenus related to public relations activities. E-agenda system has proven effective in supporting archive management at school. Based on the results of T-Test, it is known that $\mathrm{T}$ count is -42.799 . The value of $\mathrm{T}$ table at confidence level of 95 per cent is 1.99045 by ignoring the mathematical sign $(-)$ then $\mathrm{T}$ table $<\mathrm{T}$ count, namely $1.99045<42.799$ which means the null hypothesis were rejected, so there is a difference between the responses of the respondents before with after development of the model. Based on the hypothesis can be defined that there is a difference in valuation of the respondent before and after the development of the model.

A-agenda system is easy to implement and it also does not require an expensive cost in the development of the system. But it should be noted that the school must have a strong commitment related to the archive management at school by setting guidelines for archive management, completing the facilities and infrastructure of archive management, and providing the training for officers of the archive.

\section{Conclusions}

The results showed that e-agenda system can support better archive management. Therefore; it is suggested for administrative officer at school to implement e-agenda system to support archive management because e-agenda system easy to implement and does not require expensive fees to design it.

\section{ACKNOWLEDGMENT}

The researcher expresses our thankful to all of informants and respondents in this research. In this valuable chance, the researcher intended to express our gratitude and appreciation to all of them. 


\section{REFERENCES}

[1] Amos Oyetunde Alabi. 2017. Records Keeping for Effective Administration of Secondary Schools. Journal of Public Administration and Governance. Volume 7. Page 66-74. http://jpag.macrothink.org

[2] Omoha Fatu Dorcas. 2013. Management of School Records in Secondary Schools in Otukpo Education Zone. Thesis. Nsukka: University of Nigeria.

[3] Nwagwu, N.A. 2000. Funding and financial Management in Nigeria tertiary institutions. In Okeke E.A.C. Improving Effectiveness and Efficiency in the Management of Today's Tertiary Institutions. Nsukka: Institute of Education.

[4] Allahmagani, Khali. 2015. Records Management in Government Secondary Schools: The Case Study of Kaduna North Local Government, Kaduna, and Kaduna State, Nigeria. IOSR Journal of Humanities and Social Science (IOSR-JHSS). Volume 19. Page 55-60. www.iosrjournals.org

[5] Burcak Senturk. 2013. The Use of Archives in Education: Examples from Abroad. International on New Trends in Education and Their Implication. Volume 4. Page 108-114.

[6] Usen, S.M., Udofia, A.E., \& Offiong, A.A. 2012. Effective Management of Wastages in Vocational Education for Sustainable Development in Nigeria. African Research Review. Volume 6. Page 176-187.

[7] Oluwole, M.U. and Ivagher, Ezekiel Dondo. 2015. Record Keeping and Effective Management of Secondary Schools in Zone B Senatorial District of Benue State, Nigeria. European Open Educational Research Journal. Volume 1. Page 1-13. http://eurpub.com/journals.php

[8] Osakwe, N.R. (2011). Management of School Records by Secondary School Principals in Delta State, Nigeria. The Social Sciences. Volume 6. Page 40-44.

[9] Kemoni H., Wamukoya J. 2000. Preparing for the mangement of electronic records at Moi Kenned Jay \& cherryl Schauder (1998). Records Management: A Guide to Corporate Record Keeping. Melbourne: Longman.

[10] Philip Usman Akor and Julie Udensi. 2014. An Assessment of Record Mangement System in Establishment Division of Two Universities in Nigeria. International Letters of Social and Humanistic Sciences.Volume 13. Page 97-109. Doi:10.10852/www.scipress.com/ILSHS.13.97

[11] Rose Ngozi Amanchukwu, Nwachukwu Prince Ololube. 2015. Excellent School Records Behaviour for Effective Management of Educational Systems. Human Resource Management Research. 5(1). Page 12-17.

[12] Seniwoliba, A.J., Mahma, A.V., and Abilla, B.J. 2017. Challenges of records management in higher education in Ghana: The case of University for Development Studies.International Journal of Educational Policy Research and Review. Volume 4. Page 29-41. https://doi.org/10.15739/IJEPRR.17.005

[13] Oktarina, Nina, dkk. 2015. School Accountability based on E-Archive at Senior High School in Semarang. International Journal of The Computer, The Internet And Management. Volume 23 number 3. Page 24-26.

[14] Oktarina, Nina, dkk. 2017. Developing Model of School Accountability Based on Archive. Research Report.

[15] Borg, R Walter \& Gall, Meredith D. 1989. Educational Research an Introduction Fifth Edition. New York: Longman.

[16] Sugiyono. 2017. Education Research Method. Alfabeta.

[17] Moleong, Ley.2014. Qualitative Research Method. Remaja Rosdakarya 